Orbital Elements of Two Meteors.-From a number of observations of a meteor which was seen on August 3 Dr. P. Moschick, of Heidelberg, has calculated the radiant point, the earth point, the velocity, and the height of the meteor, and also the elements of its orbit. For the apparent radiant he obtained $\alpha=317^{\circ} 56^{\prime}, \delta=-\mathrm{II}^{\circ} 54^{\prime}$, and for the mean velocity $47.93 \pm 8.37 \mathrm{~km}$. per second, the probable value for the absolute velocity being $52.74 \mathrm{~km}$. per sec. The elements show the orbit to be hyperbolic, and the meteor's motion in the orbit to be direct.

A second meteor was seen by numerous German observers on September 28, and Dr. Moschick has treated the observational results similarly. For the position of the radiant point he obtained $\alpha=354^{\circ} 54^{\prime}, \delta=+22^{\circ} 40^{\prime}$, and therefore concluded that the object observed was a Pegasid. The relative and absolute velocities were respectively $2 \mathrm{I} \cdot 5 \mathrm{I}$ and $36.4 \mathrm{~km}$. per second, and the calculated elements show that the meteor moved, with a direct motion, in an elliptical orbit (Astronomische Nachrichten, No. 4057).

Magnetic Disturbance during the Recent Auroral DisPlay. - In a paper communicated to the Paris Academy of Sciences, M. Th. Moureaux states that a strong magnetic disturbance took place about 9 o'clóck on November 15, coinciding, in point of time, with the exceptionally fine auroral display which was so generally observed. From $8 \mathrm{~h} .59 \mathrm{~m}$. to $9 \mathrm{~h}$. $9 \mathrm{~m}$. (Paris M.T.) the declination, which was already below the normal, diminished by $34^{\prime}$, and then quickly recovered, increasing $42^{\prime}$ between $9 \mathrm{~h} .9 \mathrm{~m}$. and $9 \mathrm{~h} .24 \mathrm{~m}$. The horizontal and vertical components were simultaneously affected in the opposite direction. Similar disturbances took place on November 12. Numerous small groups of sun-spots were on the solar disc during this period, and the first large group seen in October, now much scattered and diminished, was due to cross the central meridian on the evening of November 13, during its second rotation (Comptes rendus, No. $2 \mathrm{I}$ )

The Zodiacal Light to the North of the Sun.-Whilst in Switzerland recently, Prof. Newcomb ascended the Brienzer Rothorn in order to observe, if possible, the extension of the zodiacal light in the north and south direction. He found that the light was bright enough to be seen at a distance of $35^{\circ}$ from the sun in the direction of the solar axis, and he assumes that it extends equally on both sides. Prof. Newcomb therefore suggests that the zodiacal light shall in future be described " as a luminosity surrounding the Sun on all sides, of which the boundary is nowhere less than $35^{\circ}$ from the Sun, and which is greatly elongated in the direction of the ecliptic" (Astrophysical Journal, No. 3, vol. xxii.).

\section{CANADIAN ELECTRIC POWER STATIONS AT NIAGARA.}

$\mathrm{N}$ January 2 of this year, in the power house of the Canadian Niagara Power Company, on the Canadian side at Niagara, the largest units used in the development of water-power were started. This great power house is situated in Victoria Park, and all the work of development is done under consent from the Government of the Province of Ontario and the commissioners of the park.

Fourteen years ago ground was broken on the New York side at Niagara for a power development by means of a wheel-pit and tunnel. The 105,000 horse-power thus developed has been a great inspiration to the growth of the American city, and Canadians looked forward to the time when they should profit by a similar development. Now their hopes are being realised, for three strong companies are actively at work on the Canadian side developing power from the water that speeds toward the Horseshoe or Canadian Fall. It was in 1892 that the Canadian Niagara Power Company secured its first rights to develop power in Canada, and since then it has paid the park commissioners more than 225,000 dollars in the retention of its privileges, while its first horse-power was developed on the date above mentioned.

The Canadian Niagara Power Company is allied to the Niagara Falls Power Company of the New York side of the river, but in its Canadian development it has given men of science and electrical engineers the most wonderful NO. 1885 , VOL. 73] installation to study yet known in the field of any water power development. In the big power houses on the New York side the unit of development is 5000 horse-power, but on the Canadian side the unit is ro,ooo horse-power. I was in 1890 , at a meeting of the International Niagara Commission, held in London, that a unit of 5000 horsepower was adopted for the development on the American side at Niagara.

Ten years have elapsed since Rudolph Baumann, a Swiss engineer, turned the wheel that started the first 5000 unit on April 4, 1895, and since that day the installation has been doubled in size and output capacity, and is in every way a success. Now comes Canadian Niagara with its units of 10,000 horse-power, the largest in the world. $\mathrm{Mr}$. William H. Beatty, of Toronto, Ontario, who is president of the Canadian Niagara Power Company, turned the small wheel that controls the flow of water from the penstocks to the turbines, and as he admitted the flood of water the monster generator began to revolve, and within a few minutes was making 250 revolutions a minute, the speed at which it is to be steadily operated. Unit No. 2 was also started, making 20,000 horse-power available in the

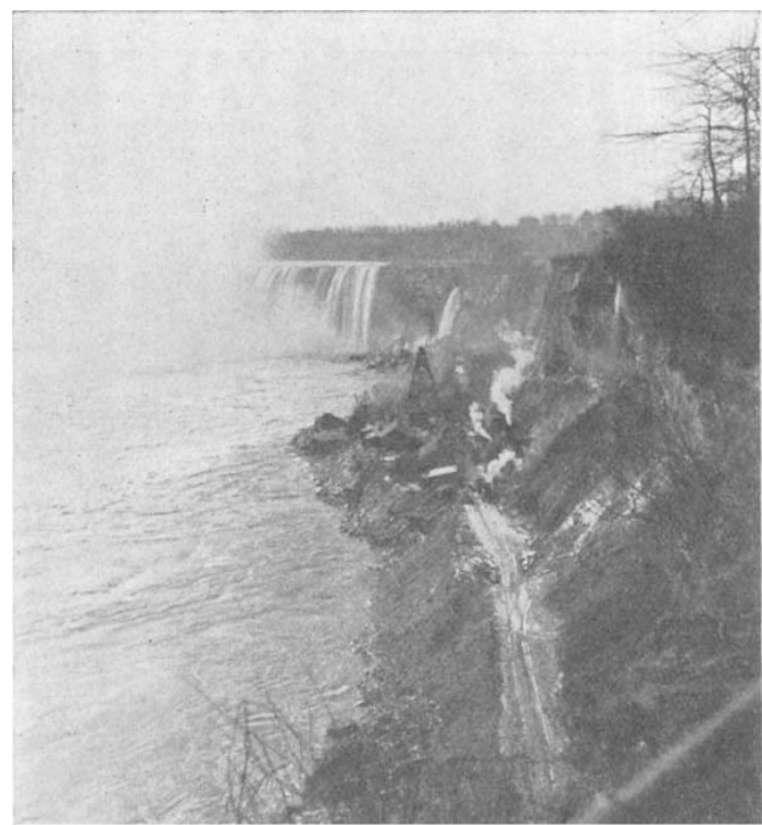

FIG. I.-Site of the Power House of the Ontario Power Co., showing its nearness to the Horseshoe Fall.

station, and by May I three additional units of the same size were ready to run, giving off a total of 50,000 horsepower from the five machines. In all, eleven units will be installed in this station, so that its final output will be I I , ooo horse-power, or 5000 horse-power more than is available from the twenty-one machines in the two power houses of the Niagara Falls Power Company on the American side of the river.

In the wheel-pit and tunnel method of developing power at Niagara, a great slot, several hundred feet long, is excavated in the earth to a depth of about r8o feet and 2 I feet wide. From the bottom of the wheel-pit a tail race or tunnel is driven through solid rock a distance of 2200 feet to the lower river or gorge. This tunnel is built in the form of a horseshoe, and is about 20 feet wide by 25 feet high. It is lined from end to end with vitrified brick and concrete, while the wheel-pit is also carefully lined. From the upper river a canal of short length diverts water from the main stream to a forebay at one side of the big power house. Near the bottom of the wheel-pit the turbines are installed, and these are connected to the generators in the power station over the wheel-pit by vertical shafts or tubes. From the forebay to the turbines penstocks ro feet in diameter run to the turbines, and as 
the gates are raised the water pours from these penstocks into the wheels that give motion and life to the big generators. As the water passes through, or is discharged from, the turbines, it falls into the tunnel, and then flows through this tail race to the lower river and gorge. It is diverted from the main stream but a very few minutes, but in that time it serves to aid man in gaining control of thousands of electrical horse-power.

It is agreed between the power companies and the commissioners of Victoria Park that all power generated in the park limits must be transmitted outside the park boundaries for application and use, and so the electric current from the station referred to will pass to a transformer station not far distant, where, for transmission purposes, it will have its voltage raised to 40,000 or 60,000 volts, in order that it may successfully and economically be sent to Toronto and other distant places to meet the demand for electric power from Niagara. Toronto has long been anxious to be connected by a transmission line with the power development at the falls, and now a line for transmission purposes has been about completed, so that electric current from the generators in the station of the Canadian Niagara Power Company may be used in the

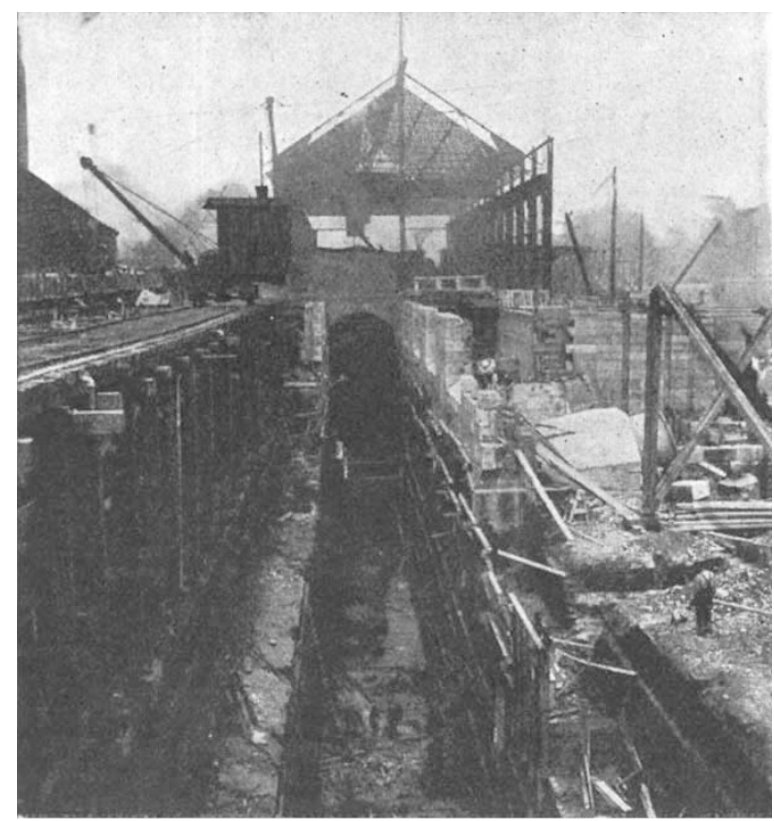

Fig. 2.-Power House of Canadian Niagara Power Co., being erected over the wheel-pit.

operation of the trolley cars and lighting systems of the Canadian city nearly go miles away from Niagara.

The Electrical Development Company of Ontario, Ltd. is also constructing a wheel-pit and tunnel power development in Victoria Park. The works of this company will be a short distance above the site of the development of the Canadian Niagara Power Company, but, for all this, the tunnel it is building will be slightly shorter than the tunnel of the company last named, because it will run right under the river-bed, over which the upper rapids toss, to a point behind the falling sheet of water of the Horseshoe Fall, where it will empty into the lower river. From the bottom of this wheel-pit there will be two short lateral tunnels that will carry the water from the pit to the main tunnel at a point 165 feet from the bottom of the slot. This company projects a development of about i25,000 horse-power, and the machinery it will instal will command general attention.

The Ontario Power Company is another concern that has secured a franchise for the development of power in Victoria Park. Its method of development will be quite different from that of the other two companies referred to. Its power house, a concrete and iron structure, has been built at the water's edge, in the gorge, a short distance below the Horseshoe Fall, and water will be carried to it by penstocks concealed from view in tunnels that have been driven through the rocky bank from a spillway or open relief on top of the bank. From this spillway great steel flumes will extend to the forebays, which are situated far up the river. There will be three of these steel flumes, each I 8 feet in diameter and more than 6000 feet long. Each will divert 3900 cubic feet of water every second, which is an amount estimated to be sufficient to develop 60,000 electrical horse-power in the station at the water's edge. Thus from the three steel flumes and the water supply thus afforded, no less than 180,000 horse-power is to be developed. This power will pass from the generators to a transformer station located on the bluff in the rear of Victoria Park more than 250 feet above the power house, and more than 550 feet back from it.

Orrin. E. Dunlap.

\section{INVESTIGATION OF THE UPPER AIR.}

THE subjoined announcement has been received from the director of the Meteorological Office.

In response to representations from various quarters, the Meteorological Committee has assigned from the Parliamentary grant under its control a sum for promoting the investigation of the upper air by kites and other means.

The immediate objects in view are:-(1) To establish an experimental station where kite ascents and other experimental investigations can be carried out, especially on the days selected for international cooperation. (2) To develop and extend the instrumental equipment, so that facilities may be afforded for the cooperation of other observers upon sea or land. (3) To provide for the publication of the observations in combination with those of other countries, by a contribution to the cost of the international publication undertaken by the president of the International Commission for Scientific Aërostation, Prof. $\mathrm{H}$. Hergesell, of Strassburg.

Mr. W. H. Dines, F.R.S., has undertaken the direction of the operations for the Meteorological Office. His experiments for the office are carried on at his house at Oxshott.

An endeavour will be made, with fair prospect of success, to enlist the cooperation of marine observers in correspondence with the office. Captain A. Simpson, of the S.S. Moravian, has already expressed his willingness to make a trial of this method of extending our knowledge of marine meteorology as soon as the necessary gear and instruments can be supplied.

It is hoped that through the assistance of others who are interested in such investigations, and have at their disposal the means of carrying them out, an effective scheme for the investigation of the upper air may be set on foot. Lieut.-Colonel J. E. Capper, C.B., R.E., of the Aldershot Balloon Companies, has already facilities for such purposes, and will take part; Mr. G. C. Simpson, lecturer in meteorology in the University of Manchester, is making arrangements for occasional observations on the Derbyshire hills; Mr. C. J. P. Cave, who has already made some interesting kite ascents in Barbados, has provided himself with the necessary equipment for experiments at Ditcham Park; and Mr. S. H. R. Salmon has arranged a station on the Downs near Brighton, and carries out ascents on the international days.

There is, accordingly, a prospect of an effective investigation being commenced.

\section{BOTANY AT THE BRITISH ASSOCIATION.}

THE president, Mr. Harold Wager, F.R.S., dealt in his address, which was delivered at Johannesburg, with some problems of cell structure and physiology. The text of this address has already appeared (September 21) in NATURE.

As was to be expected, there were fewer papers than usual this year in Section $K$, and of these relatively few were of a purely technical nature, the majority being either general accounts of recent work or else papers which possessed some special local interest.

General Papers.-Prof. R. W. Phillips opened the pro-

No. 1885 , VOL. 73 